\title{
Ross W. Duffin. Some Other Note: The Lost Songs of English Renaissance Comedy. New York: Oxford University Press, 2018. Pp xxxviii, 722. Hard- back $£ 32.99$. ISBN: 9780190856601.
}

\section{DAVID MCINNIS}

University of Melbourne

Every student of early modern theatre understands, on some level, that music featured prominently in the performance of plays; Alan C. Dessen and Leslie Thomson, in their Dictionary of Stage Directions in English Drama (Cambridge, 1999), identify 630 explicit stage directions for music to sound in over 220 plays. But because even those play-texts which print lyrics typically do not include printed music to accompany them, I would suggest that very few scholars appreciate quite how extensive a role music played. Like prologues, epilogues, and letters, songs circulated independently of play-texts, leading (we might assume) to an increased propensity for loss. On rare occasions, though, a musical fragment is all that survives of an otherwise lost play-text: Tourneur's 'The Nobleman' (1611) and Fletcher, Field, and Massinger's 'The Jeweller of Amsterdam' (1616) fall into this category. ${ }^{1}$ The Early Broadside Ballad Archive (UC Santa Barbara) and Broadside Ballads Online (Oxford) have done much to catalogue extant ballads from the period, and the Arden Early Modern Drama series now offers a treble clef as a musical marker to indicate the punctuation of a scene or act by music. With Ross Duffin's comprehensive research, it should now be possible and desirable to include in critical editions the actual melodies used in plays, and for editors to include commentary analyzing intertextual uses of those melodies in other drama of the period.

At the heart of Duffin's book is the simple yet eminently sensible observation that because playwrights were not usually also composers, they 'wrote lyrics to tunes that they were humming to themselves, appropriated from music they were hearing, and that therefore shaped the lyrics as they were written' (xxiv). Duffin further claims that 'there is almost a compulsion to use some of the same key words, or rhyming words, that are in the original song' (xxv). These are powerful insights: they enable Duffin to scour the archives for period tunes that fit the lyrics in plays, and thereby identify plausible settings for the otherwise silent songs in playbooks. His inspired detective work encompasses the identification of probable cues for music within plays, including covert allusions in stage dialogue to the names or popular refrains of well-known songs; the recognition of unusual versification and rhyme schemes that enable a quasi-forensic 'match' with extant 
musical settings; and the explication of the subtleties of musical form and terminology in ways that elucidate the import of a particular tune at specific moments in a dramatic spectacle. Most helpfully, he sets the lyrics to the music he identifies as the most plausible original setting, and accompanies these with a discussion of how the song may have been sung.

Some Other Note commences with the polyphonic sophistication of non-liturgical music in fifteenth-century shepherds plays and the scatological parody of Christmas songs in Mankind as a kind of background to Renaissance musical comedy. Noting that 'Recovering plausible music to songs in comic interludes is more possible than people may think', Duffin fleshes out this background via attention to sixteenth-century 'chorus-masters, composers, and instrumentalists' involved in the production of court interludes (20): William Cornysh, John Skelton, John Heywood, and Nicholas Udall (whose Ralph Roister Doister Duffin dubs 'one of the most musical of English Renaissance comedies' [45]). As well as deciphering obscure musical terminology and combing through their plays for oblique cues for the performance of songs, Duffin offers concise biographies of each of these men, outlining with admirable succinctness their respective contributions to the formation of musical entertainment in England.

Church musicians including John Redford, Sebastian Westcott, Richard Farrant, and others form the basis of the following chapters' exploration of interludes associated with the Children of Paul's and the Chapels Royal. Duffin uses the identification of meter and form, comparison with lyrical analogues, sensitivity to intertextual allusion and parody, and other close reading methods to great effect: in one instance, he argues compellingly that, in The Marriage of Wit and Science, Will and Recreation actually 'combine two tunes for dramatic effect', singing them in contrasting moods (99). For Richard Edwards's lost 'Palamon and Arcyte' play (1566), Duffin astutely observes that, since the performance occurred in September, the reward paid to the boy actor playing Emilia for 'singinge sweeetlie in ye pryme of maye' probably alludes to the consort song When May is in his prime, which Duffin attributes to Edwards (116). Incidentally, although Duffin does not note it, this song actually appears in the same seventeenth-century miscellany, BL Add. MS 26737, fol.108r-v, as 'The songe of Emelye per Edwardes' that is usually associated with the lost Palamon play. Duffin cites the provision of rewards for choristers for 'singing of Ballads, Plays, or the like' in 1595 as evidence of the boys' familiarity with popular music, thus increasing the likelihood that 'lyrics in plays that match the versification of well-known songs would have been sung to the same tunes' (121). Songs from Lyly and Peele's plays are set to appropriate 
music here too, despite the challenge of asymmetrical lines and irregular versification (126-38).

Duffin's book is structured as a chronological survey in two parts. The individual chapters in part one form a background to the Renaissance comedy that he discusses in part two. The background chapters do not conclude with a thesis about the precise contributions of, for example, 'University and Inns of Court Interludes' (chapter five) on subsequent London comedy, so much as offer 'a colorful glimpse' of the musical material that falls within their purviews (139). (An exception, offering more explicit commentary on influence and significance, is chapter six, 'Continental Influences', which examines the musical legacy of France, Ancient Rome, Germany, and Italy in England's theatrical venues.) Even so, the reader can draw certain inferences from the material, as the singing of a tune in one play would presumably activate associations with its performance in another play and a different context, and tunes recur with somewhat astonishing frequency (Dulcina, or Robin Goodfellow twelve times; Fortune my foe twentyeight times; Packington's Pound twenty-one times).

Part two commences with Duffin's observation that, from the late 1590s, lute songs (not just popular ballads) began to appear in plays, recognizable and fit for parody. He also provides a welcome recognition that the music of indoor playhouses was not inherently more 'sophisticated' than that of the amphitheatre venues: 'the popular song repertoire continued to furnish models for plays['] songs in all venues' (198). Duffin divides this second section according to the output of individual playwrights rather than by themes or auspices, and as a reference work for the musical settings of songs in plays, it will prove indispensable for editors and producers of early modern drama. Shakespeare, the subject of Duffin's earlier Shakespeare's Songbook (New York, 2004) is deliberately absent here, but Duffin gives substantial attention to the works of Jonson, Dekker, Middleton, Fletcher, Marston, Massinger, and other major playwrights of the era, with anonymous plays and those by Haughton, Heywood, Percy, Sharpham, and others discussed collectively in chapters fifteen and sixteen. Of particular value to textual scholars will be the elucidation of notorious cruces through Duffin's plausible musicological solutions and subtle musical hints. Carlo Buffone in Every Man out sings and dances not the nonsensical 'Lomtero' (as it appears in print) but the Spanish lute solo Lantero (206). Mucedorus's line 'In tyme tofore when fortune did not frowne', which occurs shortly after a stage direction for the clown (Mouse) to sing, turns out to be an allusion to the song Fortune, my foe, why dost thou frown on me?, strongly suggesting that Mouse sang that precise song and that Mucedorus was echoing its phrasing (603). And in order to explicate the 'Song Logicall, 
foure in Fuge' from William Percy's Mahomet and His Heaven (1601), which features puzzling choreography and only two named singers, Duffin has recourse to Thomas Morley's definition of a fugue and proposes that 'the piece may have been sung as a round, with each of the two named singers using his own lyric, stanza by stanza' (565).

Duffin is careful not to mislead readers as to the certainty of his identifications, offering transparency in argumentation: 'Not many tunes fit this versification' (254); 'A handful of tunes would fit its eight tetrameter lines in rhyming couplets, but the best match seems to be ...' (342). He openly acknowledges when there is 'not an obvious match for any existing song', or when there 'is not a strong link' between the lyric and any known tune $(429,205)$. In some instances (eg, Cynthia's Revels [207]) Duffin actively rejects extant seventeenth-century settings as unlikely to have been used in original productions.

Although we know that characters sang and played during a performance, the duration and nature of those musical interludes has hitherto remained largely elusive. Tunes can add pathos or irony to lyrics, affecting the mood and dramaturgy of a crucial scene. Some Other Note makes a vital contribution to appreciating these subtleties.

\section{Notes}

1 Digitisations and audio recordings of these musical fragments can be found in the relevant entries on the Lost Plays Database: 'The Nobleman', last modified 6 January 2017, https://lostplays.folger.edu/Nobleman, The; and 'Jeweller of Amsterdam', last modified 6 January 2017, https://lostplays.folger.edu/Jeweller of Amsterdam. 